\title{
Preparation, Characterization and Biocompatibility Study of the Scaffold Prototype Derived from Cross-Linked Poly[( $\varepsilon$-caprolactone)-co-lactide] for Tissue Engineering Materials
}

\author{
By Hiroshi MiYASAKo, Kazuya Yамамото, and Takao AOYAGI*
}

In this study, we prepared cross-Linked poly[( $\varepsilon$-caprolactone)-co-lactide] scaffolds prototype by salt-leaching method using different particle size of $\mathrm{NaCl}$. The characterization of these scaffolds were carried out the estimating internal morphology by scattering electron microscopy (SEM) and water content in PBS at $37^{\circ} \mathrm{C}$. We also studied the adhesion and proliferation of human bladder cancer cells (HBCC) to slab-type scaffold prototype by the microscopic observation of cell morphology and alamar Blue ${ }^{\circledR}$ assay. These results suggest that the prototype in this study shows good biocompatibility, because the cells adhered well and penetrated into the internal pore with incubation periods. Consequently, these results indicated that the scaffold prototype could be applied as practical scaffold for tissue engineering.

KEY WORDS: Poly( $\varepsilon$-caprolactone) / Poly(lactide) / Tissue Engineering / Scaffold / Biocompatibility / Bladder Cell /

Recently, much attention has been attracted to tissue engineering technology as new method for regeneration where the tissues have been lost through trauma or disease. ${ }^{1-6}$ As the effective strategy, use of porous scaffold is one of the essential methods for the three-dimensional tissue reconstruction. The requirements of scaffold materials are manifold and extremely challenging. First of all, biocompatibility is imperative, because the material must not elicit an unresolved inflammatory response nor demonstrate immunogenicity or cytotoxicity. Second, the mechanical properties of this material also must be sufficient and not collapse before the regenerated tissue is structurally stabilized. ${ }^{7-10}$ Moreover, degradation profiles are also important since the rate may affect many cellular processes including cell growth, tissue regeneration, and host response. ${ }^{11}$ In addition, porosity and pore size of the material should be tunable in order to optimize cell seeding, attachment, growth, extracellular matrix production, vascularization, and tissue ingrowth. ${ }^{12}$

In many cases, the scaffolds for tissue engineering are derived from aliphatic polyesters as poly(glycolic acid) (PGA), poly ( $\varepsilon$-caprolactone) (PCL), poly(lactic acid) (PLA) and these copolymers because of good biocompatibility and degradation. ${ }^{2,3,6}$ Therefore, we studied preparation, as well as physicochemical and biological characterization of CL-LA copolymer-based cross-linked materials. ${ }^{13}$ The cell culturing experiments discovered that cells adhesion and growth on the CL-LA70/30c (cross-linked membrane from CL/LA $=70 / 30$ composition) were comparable to that on the commerciallyavailable polystyrene dish. Moreover, the protein absorption experiment using the FBS revealed that materials with wellgrown cells showed better adhesion of the proteins. ${ }^{13}$

In this study, we attempted to confirm the mechanical property by tensile test and to prepare a scaffold prototype by using the same materials as described above. Since these materials possess the low melting point, they show flexibility at ambient temperature. Considering matching with the soft tissue in the human body, flexible materials are suitable. To afford the porous scaffold prototypes, salt-leaching technique ${ }^{14,15}$ was applied using branched macromonomer with CL/LA (70/ $30 \mathrm{~mol} \%$ ) and crashed and sieved $\mathrm{NaCl}$ crystals with different particle size. The morphology observation with scattering electron microscopy (SEM) and water content measurement in PBS at $37^{\circ} \mathrm{C}$ were carried out to characterize them. We confirmed the adhesion and proliferation of model cell to CL and LA copolymer-based scaffold prototype by the microscopic cell morphology observation adhered on the surface. The cell viability was investigated using alamar Blue ${ }^{\circledR}$ assay.

\section{EXPERIMENTAL}

\section{Materials}

Xylene, sodium chloride $(\mathrm{NaCl})$, and Trypan Blue were purchased from Wako Pure Chemical Industries Ltd. (Osaka, Japan). The model cell, human bladder cancer cells (HBCC) were established by Medical school of Kagoshima University. ${ }^{16,17}$ Fetal Bovine Serum (FBS) was purchased from Gemini Bio-Product (USA). Dulbecco's Modified Eagle's Medium, Dulbecco's phosphate buffered saline, TrypsinEDTA solution, Penicillin-streptomycin solution, and benzoyl peroxide (BPO) were purchased from Sigma (St. Louis, MO, USA). The alamar Blue ${ }^{\circledR}$ indicator dye was purchased from TREK Diagnostic Systems, Inc. (USA). The $25 \%$ glutardialdehyde was purchased from MERCK (Tokyo, Japan), and diluted by $\mathrm{PBS}(-)$ prior to use.

Branched poly( $\varepsilon$-caprolactone-co-D,L-lactide) that molar ratio was 70:30 (abbreviated as CL-LA70/30) was synthesized

Department of Nanostructure and Advanced Materials, Graduate School of Science and Engineering, Kagoshima University, 1-21-40 Korimoto, Kagoshima 890-0065, Japan

*To whom correspondence should be addressed (Tel: +099-285-7794, Fax: +099-285-7794, E-mail: aoyagi@eng.kagoshima-u.ac.jp). 


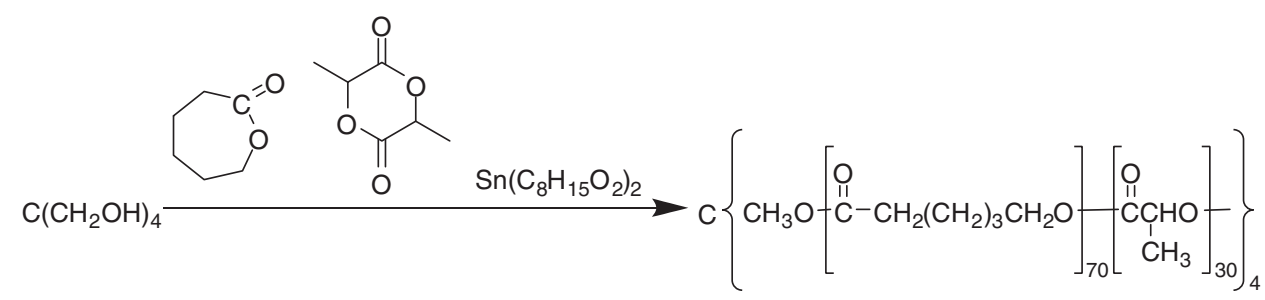

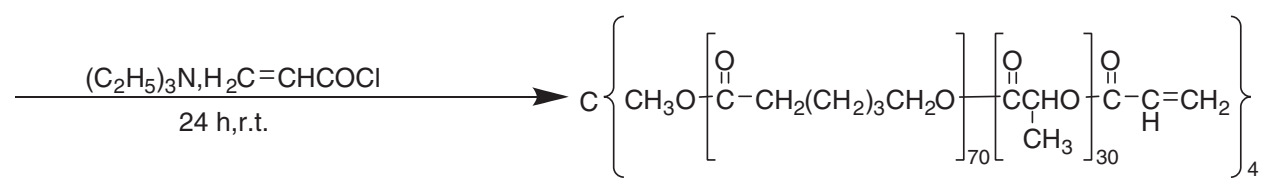

Scheme 1. Schematic illustrations of CL-LA70/30m

by ring opening polymerization in bulk using tin octanoate as a catalyst and pentaerythritol as an initiator. The number average molecular weight, weight average one and molecular weight distribution were 22500,35900 and 1.59 , respectively. The corresponding macromonomers (abbreviated as CL-LA70/ $30 \mathrm{~m}$ ) were then prepared by introducing an acryloyl group at the chain ends. The synthetic procedure is shown in Scheme 1. The synthesis method of CL-LA70/30m and cross-linked CLLA70/30c were reported by our previous literature. ${ }^{13}$

\section{Fabrication of Cylindrical Type Scaffold Prototype}

The macromonomer, CL-LA70/30m (1.0 g) was dissolved with $3.41 \mathrm{~mL}$ of xylene solution containing BPO (0.009 $\left.\mathrm{gm} \mathrm{L}^{-1}\right)$. Crashed crystals of $\mathrm{NaCl}(9.0 \mathrm{~g})$ were sieved at size of 53-106 $\mu \mathrm{m}, 106-150 \mu \mathrm{m}, 150-250 \mu \mathrm{m}$ and $250-500 \mu \mathrm{m}$ and then added to the solution. The mixture was well mixed and placed in the cylindrical sample tube with $3.4 \mathrm{~cm}$ by height and $1.0 \mathrm{~cm}$ in diameter. These tubes were then placed in an oven at $80^{\circ} \mathrm{C}$ for $2 \mathrm{~h}$. The cylindrical-type sample was taken from the tube and immersed in a large amount of acetone to remove an unreacted compound. This sample was then immersed in distilled water to leach out $\mathrm{NaCl}$, and washed thoroughly and dried under reduced pressure. The obtained sponge-type sample was used for scaffold properties evaluation. The sample name was abbreviated as CL-LA70/30sc (CL and LA contents was 70:30 molar ratio).

\section{Preparation of Slab-type Scaffold Sample}

The slab-type sample was also prepared using same components as described above for adhered cell study. In this case, $\mathrm{NaCl}$ with $250-500 \mu \mathrm{m}$ in diameter for pore formation, two glass plates with a $4 \times 4 \mathrm{~cm}^{2}$ and $1.0 \mathrm{~mm}$ of silicon frame spacer were used to achieve the purpose. Other procedure was the same as described above and the samples are abbreviated as CL-LA70/30ss.

\section{Characterization}

The porosity of the prepared samples was estimated by weight loss after $\mathrm{NaCl}$ leaching according to the following eq 1

$$
\text { Porosity }(\%)=100\left(1-\rho / \rho_{0}\right)
$$

where $\rho_{0}$ and $\rho$ are the densities of the non-porous cross-linked material and the obtained sample, respectively. They were calculated by dividing the weight by the volume of non-porous cross-linked materials and these scaffolds.

The thermal properties of the cylindrical- and slab-type samples were investigated by differential scanning calorimeter (DSC) (DSC6100, Seiko Instruments, Chiba Japan). The measurements were carried out from 0 to $120^{\circ} \mathrm{C}$ at the heating rate of $5^{\circ} \mathrm{C} \mathrm{min}^{-1}$. SEM clarified the internal morphology and pore size of these cylindrical type samples.

The water content were evaluated in $\operatorname{PBS}(-)$ at $37^{\circ} \mathrm{C}$. The percentage of water content was measured by gravimetry according to the eq 2

$$
\text { Water content }(\%)=\left(\mathrm{W}_{\mathrm{t}}-\mathrm{W}_{0}\right) / \mathrm{W}_{0}
$$

where $\mathrm{W}_{0}$ is the weight of the scaffolds itself and $\mathrm{W}_{\mathrm{t}}$ is the weight after containing medium at scheduled interval.

We also evaluated the mechanical property of the starting material, CL-LA70/30c. The experiment was carried out on square specimens using a tensile testing machine, Little Senstar LSC-1/30 (Tokyo Testing Machine Co., Japan). The square specimens with $10 \mathrm{~mm}$ width and $30 \mathrm{~mm}$ length were from the prepared CL-LA70/30c having $0.2-0.3 \mathrm{~mm}$ thickness. The both ends of these specimens were fixed, and strained by a crosshead speed of $1 \mathrm{~mm} \mathrm{~min}^{-1}$.

\section{Culture of Human Bladder Cancer Cells}

The supplied human bladder cancer cells were sub-cultured in the D-MEM supplemented with 5\% FBS and penicillin $\left(100 \mathrm{U} \mathrm{mL}^{-1}\right)$ and streptomycin $\left(0.1 \mathrm{mg} \mathrm{mL}^{-1}\right)$ solution in humidified environment of $5 \% \mathrm{CO}_{2}$ at $37^{\circ} \mathrm{C}$. Subsequently, they were rinsed by $\operatorname{PBS}(-)$ and harvested from $\operatorname{PBS}(-)$ containing trypsin-EDTA solution.

\section{Cell Adhesion and Growth}

The slab-type scaffold samples were cut into circular pieces ( $6 \mathrm{~mm}$ diameter) and placed on the bottom of 96-well culture 
plate and fixed with stainless rings. $70 \%$ ethanol was added to each well to sterilize them for $1 \mathrm{~d}$. After removing the ethanol solution, they were repeatedly washed with $\mathrm{PBS}(-)$ and centrifuged in $\mathrm{PBS}(-)$ at $1000 \mathrm{rpm}$ at $25^{\circ} \mathrm{C}$ for $15 \mathrm{~min}$ to clean thoroughly. ${ }^{18}$ The cell suspension was then prepared by D-MEM (include penicillin) with $10 \% \mathrm{FBS}$ and added to the culture plate at the concentration of $3.2 \times 10^{3}$ cells cm$^{-2}$. The culture system was kept in a humidified environment of $5 \%$ $\mathrm{CO}_{2}$ at $37^{\circ} \mathrm{C}$. After 1,3 , and $7 \mathrm{~d}$ culturing periods, these scaffold samples were gently washed with $\operatorname{PBS}(-)$ to remove an un-adhered cells.

They were then fixed in $2.5 \%$ glutardialdehyde for $4 \mathrm{~h}$ and dehydrated in 30\%, 50\%, 90\%, $100 \%$ ethanol for every 5 min. After drying, they were stained by Trypan Blue and swelled by immersing in ethanol to observe by the inverted microscopy. The cells on the surface were observed by inverted microscopy (ECLIPSE TS100, Nikon, Japan Tokyo) using a digital camera (DS-L1 and DS-5M, Nikon, Japan Tokyo).

In separate experiments, alamar Blue ${ }^{\circledR}$ was used to evaluate the cell growth on the scaffold. ${ }^{19,20}$ After the same periods, $20 \mathrm{vol} \%$ of the alamar Blue ${ }^{\circledR}$ solution was added to the wells against the total culture medium. Then the plate was incubated for $6 \mathrm{~h}$. After that, $20 \mu \mathrm{L}$ of the medium was translated to 96wells black plate, and then diluted with $80 \mu \mathrm{L}$ of $\mathrm{PBS}(-)$. The fluorescence intensities of the mixture solution were measured by a fluorescence plate reader (ARVO MX 120-032, PerkinElmer, Japan, Yokohama) set at excitation and emission wavelengths of $544 \mathrm{~nm}$ and $590 \mathrm{~nm}$, respectively.

\section{Statistical Analysis}

The data from the cell growth and protein absorption studies are presented as the mean \pm SEM of three or more experiments and a statistically significant difference between each result was confirmed by the Student t-test.

\section{RESULT AND DISCUSSION}

\section{The Characters of the Starting Material}

In general, native and un-reactive PLA and PLGA are used as a scaffold for hard tissue such as bone, because the glass transition temperature, $T_{\mathrm{g}}$ of these polymers are relatively high and stiff enough to keep the shapes themselves at ambient temperature. Therefore, we intended to design the flexible and soft scaffolds to match with the soft tissues in the human body. We carried out the fundamental studies in terms of synthesis, characterization and protein adhesion as well as cell proliferation as reported. ${ }^{13}$ The branched CL and LA copolymers and the corresponding macromonomers were prepared by a ringopening copolymerization using tin octanoate as a catalyst and pentaerythritol as an initiator, followed by introducing acryloyl group at the chain ends. By the cross-linking reaction, we could control the shape according to the desired mold, even though the materials would possess the low $T_{\mathrm{g}}$. That is why such macromonomer is surely useful to fabricate the scaffold. In that experiment, the membrane-type sample was supplied to the cell

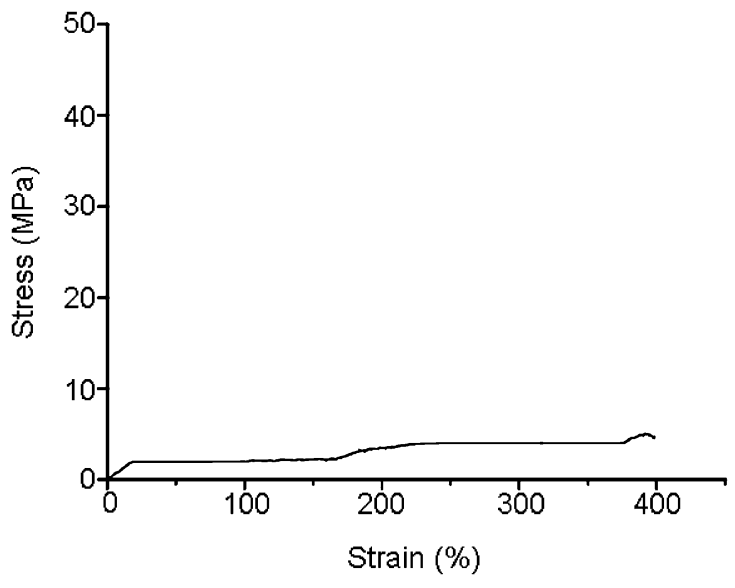

Figure 1. The S-S curve of the CL-LA70/30c.

Table I. The mechanical property of CL-LA70/30c

\begin{tabular}{ccc}
\hline & $\begin{array}{c}\text { Tensile strength } \\
(\mathrm{MPa})\end{array}$ & $\begin{array}{c}\text { Strain at break } \\
(\%)\end{array}$ \\
\hline CL-LA70/30c & $5.5 \pm 0.7$ & $437.0 \pm 54.0$ \\
\hline
\end{tabular}

adhesion study. This flat material composes of CL and LA random copolymer that composition was 70/30 molar ratio. It is rubbery at the ambient temperature.

The mechanical property of CL-LA70/30c was shown in Figure 1 and Table I. The tensile strength and strain at break of the CL-LA70/30c were 5.5 $\pm 0.7 \mathrm{MPa}$ and $437.0 \pm 54.0 \%$, respectively (Table I). As seen Figure 1, the S-S curve of CLLA70/30c also showed the same behavior as that of the typical rubber at room temperature. As a matter of fact, some researchers studied the mechanical properties of the lactidebased materials. ${ }^{21-23}$ For example, Karikari et al. reported that the photo-cross-linked materials could be prepared by using star-shaped poly(D,L-lactide) and their tensile strength and elongation at break were 8-21 MPa and 43-172\%, respectively. ${ }^{21}$ Shen et al. also succeeded in preparation of flexible films by using poly( $\varepsilon$-caprolactone-co-lactide-co-glycolide) diacrylate (the tensile strength; $2.39-3.76 \mathrm{MPa}$, strain at break; $21-$ $176 \%) .{ }^{22}$ Additionally, Nagahama et al. prepared the cast film by using star-shaped 8-arms poly(ethylene glycol)-poly(lactide) block copolymer, and evaluated to thermal property, mechanical property and biocompatibility of these films. ${ }^{23}$ According to their results, the tensile strength and strain at break of these cast films were about 5.0-10.0 MPa and 100$150 \%$, respectively. Thus, it is undoubted that the CL-LA70/ 30 s in this study was very flexible and rubbery materials. These results suggest that the flexible CL-LA70/30c is based on the low $T_{\mathrm{g}}$ by copolymerization of CL and LA as well as the highly branched structure.

Moreover, the model cell, HeLa cells adhesion and growth on the material are comparable to that on the commerciallyavailable polystyrene dish. The protein absorption experiment using the FBS proteins revealed that the materials with well- 
Table II. Preparation and characterization of CL/LA scaffold materials

\begin{tabular}{|c|c|c|c|c|c|c|c|c|}
\hline & Shape & $\begin{array}{c}\text { Polymer } \\
\text { concentration } \\
\text { (wt.-\%) }\end{array}$ & $\begin{array}{c}\text { BPO } \\
\text { (wt.-\%) }\end{array}$ & $\begin{array}{c}\text { Particle size } \\
\text { of } \mathrm{NaCl} \\
(\mu \mathrm{m})\end{array}$ & $\begin{array}{c}\text { Salt } \\
\text { content } \\
\text { (wt.-\%) }\end{array}$ & $\begin{array}{c}\text { Porosity } \\
(\%)\end{array}$ & $\begin{array}{c}T_{\mathrm{m}} \\
\left({ }^{\circ} \mathrm{C}\right)\end{array}$ & $\begin{array}{c}\Delta \mathrm{H} \\
(\mathrm{mJ} / \mathrm{mg})\end{array}$ \\
\hline CL-LA70/30sc53 & Cylinder & 25 & 3 & $53-106$ & 90 & $77.6 \pm 5.3$ & 38.7 & 43.0 \\
\hline CL-LA70/30sc106 & Cylinder & 25 & 3 & $106-150$ & 90 & $80.0 \pm 4.8$ & 39.0 & 36.2 \\
\hline CL-LA70/30sc150 & Cylinder & 25 & 3 & $150-250$ & 90 & $86.0 \pm 4.1$ & 38.9 & 43.4 \\
\hline CL-LA70/30sc250 & Cylinder & 25 & 3 & $250-500$ & 90 & $86.0 \pm 3.2$ & 38.4 & 44.2 \\
\hline CL-LA70/30cc & Cylinder & 25 & 3 & - & - & - & 38.1 & 42.8 \\
\hline CL-LA70/30ss250 & Slab & 25 & 3 & $250-500$ & 90 & $85.2 \pm 2.6$ & 37.9 & 31.0 \\
\hline
\end{tabular}

grown cells showed better adhesion of the proteins. Therefore, we attempted to prepare porous and soft scaffold prototype using the same macromonomer. Now, we adopted salt-leaching technique $^{14,15}$ because of an easiness and practicality in preparation process. Moreover, many researchers also prepared the scaffold by salt-leaching technique, and evaluated to the practicality for tissue engineering material. Lee et al. reported that the sponge-like scaffold could be prepared by salt leaching and solvent casting methods using grafted copolymer of chondroitin sulfate- $g$-L-lactide, and served as a potential candidate for cartilage tissue engineering by resulting of the biocompatibility test as MTT assay, histological examination, RT-PCR analysis and so on. ${ }^{14}$ Srivastava et al. also synthesized by ring ring-opening polymerization of $\varepsilon$-caprolactone and 1,5dioxepan-2-one using enzyme as catalysis, and evaluate to the usefulness for tissue engineering of the porous scaffold prepared by salt-leaching technique. ${ }^{15}$ So, we prepared the scaffold prototype by salt-leaching technique, and evaluated to the porosity, internal morphology, water content, and in vitro test of the cells.

\section{Preparation of Scaffold Prototype}

Table II shows the preparative condition and characterized results of the scaffold prototype. First, we optimized that macromonomer concentration at $25 \mathrm{wt} \%$ in the solution was the best for the successful preparation, because of a good dispersion of the crashed $\mathrm{NaCl}$ particles for pore formation. The prototype from the present condition is flexible sponge as seen in Figure 2. The thermal properties were listed in Table II and Figure 3 indicated the DSC curve. As a result, the melting point $\left(T_{\mathrm{m}}\right)$ and enthalpy change $(\Delta \mathrm{H})$ were determined to be about $37^{\circ} \mathrm{C}$ and $42 \mathrm{~mJ} \mathrm{mg}^{-1}$, respectively. In this case, the temperature was higher and enthalpy change was larger compared with the previous sample from the same macromonomer. It might due to the macromonomer concentration. As reported, the concentration was closely related the thermal properties. ${ }^{24} \mathrm{We}$ also evaluated the porosity of the prototype. The porosity and size control are very important for the practical scaffold fabrication, because of nutrition supply and gas exchange enough to maintain the cell viability. To estimate the porosity, many researchers have reported a gravimetry ${ }^{25,26}$ or a liquid displacement method. ${ }^{27-29}$ Other researchers also applied mercury intrusion porosimetry ${ }^{25,30-32}$ and various computer analysis software of SEM. ${ }^{33,34}$ For example, Hu et al. evaluated the porosity of the scaffold prepared from

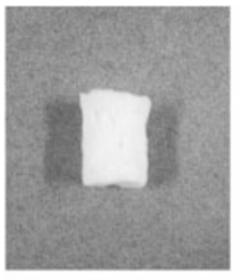

CL-LA70/30sc250

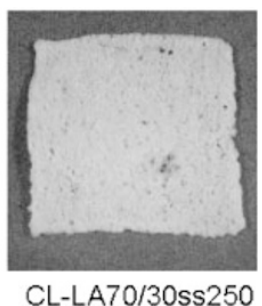

CL-LA70/30ss250
Figure 2. Photograph of CL-LA70/30sc250 (a) and CL-LA70/30ss250 (b).

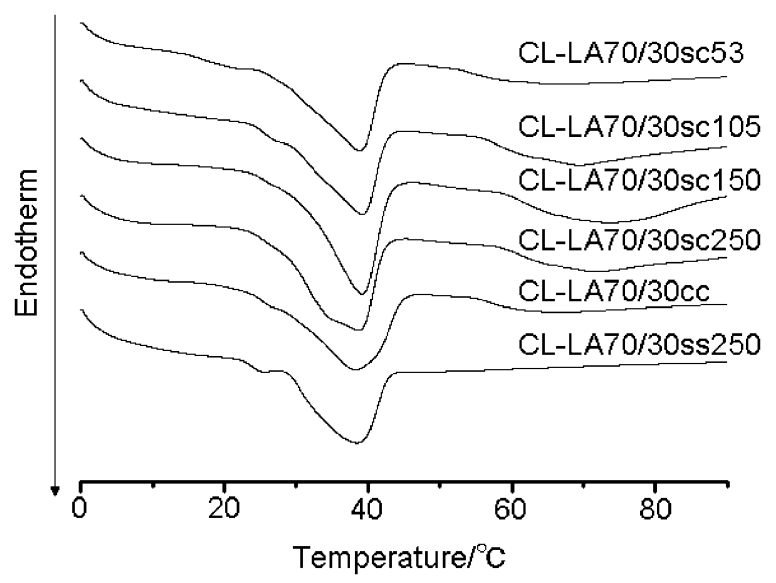

Figure 3. DSC thermograms of the cylindrical- and slab-type samples.

PLA/PLGA by gravimetry at room temperature. ${ }^{26}$ Zhang et al. adopted the liquid displacement method to estimate the porosity of the composite foams prepared from polymer/ hydroxyapatite/dioxine mixtures by using ethanol. ${ }^{28} \mathrm{Hu}$ et al. used the density value $\left(1.25 \mathrm{~g} \mathrm{~cm}^{-3}\right)$ of the $670 \mathrm{kDa}$ PLA for calculation of the polymer. For correct estimation, we measured the actual density of the materials from the nonporous cross-linked materials. The estimated results were shown in Table II. As shown, the porosity closely depended on the particle size of crashed $\mathrm{NaCl}$. The smaller $\mathrm{NaCl}$ particles we use, the smaller pores were. It is suggested that the scaffold prepared by using small particle size of $\mathrm{NaCl}$ could be constricted by purification process and reduced pressure dry. Anyway, it is proved that these scaffolds were highly porous structure, because the porosity of these scaffolds was a range from $77.6 \pm 5.3 \%$ to $86.0 \pm 3.2 \%$. 


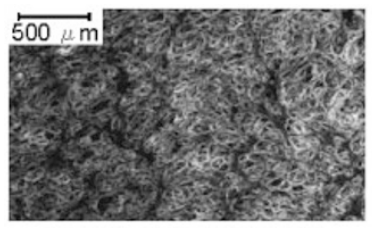

(a) CL-LA70/30sc53

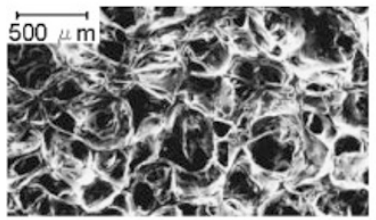

(d) CL-LA70/30sc250

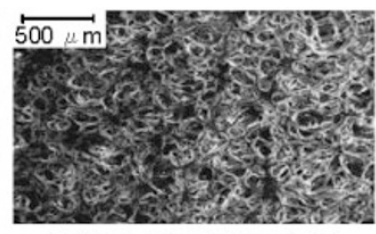

(b) CL-LA70/30sc 106

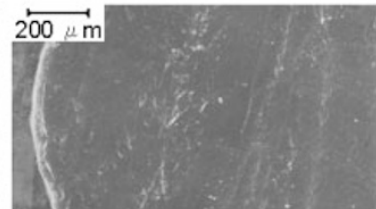

(e) CL-LA70/30cC

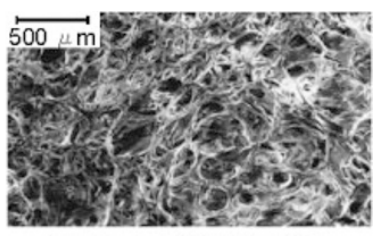

(c) CL-LA70/30sc150

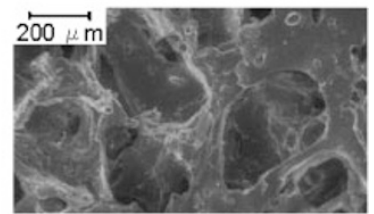

(f) CL-LA70/30ss 250

Figure 4. Morphological observation by SEM of cylindrical- and slab-type samples.

\section{Structure of Scaffold Prototype}

Figure 4 shows SEM views of the cylindrical scaffold prototype. We can see the well-developed porous structure, consisting of open pore channel and inter connected framework. CL-LA70/30cc (Figure 4(e)) (without the salt) did not show any pores. Consequently, it is suggested that CL-LA70/ 30sc53, CL-LA70/30sc106, CL-LA70/30sc150 and CLLA70/30sc250 prepared were the porous materials by using very effective salt-leaching technique. The pores of these scaffolds also slightly contracted, but the sizes were controlled by the particle size of the salts. Especially, Figure 4(f) shows SEM photograph of CL-LA70/30ss250 (slab-type sample). The internal morphology of slab-type material showed a porous structure and internal connected framework as well as that of cylindrical type scaffold.

The water uptake in a scaffold is important aspects because of the supply cell growth environment for tissue engineering. ${ }^{35-38}$ Therefore, we evaluated the water uptake of scaffold by gravimetry in $\mathrm{PBS}(-)$ at $37^{\circ} \mathrm{C}$. The water content of these cylindrical scaffolds was shown in Figure 5. CL-LA70/30sc53, CL-LA70/30sc106, CL-LA70/30sc150 and CL-LA70/ $30 \mathrm{sc} 250$ absorbed water very rapidly with about $15 \mathrm{~min}$, and then gradually reached equilibrium for about $24 \mathrm{~h}$. The ratio of water uptake was very high at $300 \%$, when water uptake of

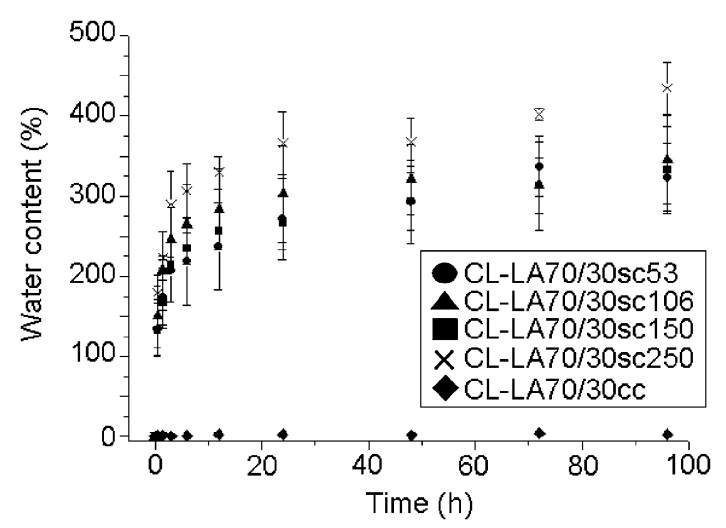

Figure 5. Water uptake at $37^{\circ} \mathrm{C}$ in $\mathrm{PBS}(-)$ of cylindrical-type samples. these scaffolds was reached equilibrium. Additionally, each sample could hold the water in the porous structure, because the water weight in these materials did not decrease even after $24 \mathrm{~h}$, whereas CL-LA70/30cc (non-porous sample) did not absorb water. These results suggest that the prototype prepared in this study could uptake and preserve the large amount of water in its pores enough to provide the cell growth environment.

\section{Cell Proliferation in the Scaffold Prototype}

In this study, human bladder cancer cells (abbreviated as HBCC) were used to study the feasibility as the scaffold. Generally, lactide and glycolide-based copolymers are relatively stiff because of their higher $T_{\mathrm{g}}$. Therefore, they are suitable for such bone and cartilage regeneration., ${ }^{3,4,28,30,31} \mathrm{On}$ the other hand, in terms of the scaffold for soft tissues or organs such bladder that require retractility, soft and flex scaffold would be appropriate. Hence, we intended to design the soft scaffold prototype with rubbery character. Hydrogel are also studied aiming at extra-cellular matrix, however, the mechanical strength seem to be not satisfied. ${ }^{39-41}$

Figure 6 shows the cell morphology of the HBCC adhered on the CL-LA70/30sm250 after 1, 3, and $7 \mathrm{~d}$ culturing periods. The low magnification of the microscope was applied for survey the cell morphology on the surfaces of the prototype. As seen in the figure, the HBCC are well adhered and extended on the CL-LA70/30sm250 surface. Moreover, Figure 7 indicated highly magnified picture on the same prototype. The cells go into the pores and adhere and spread on the inner surfaces.

In Figure 8, we confirmed the cells growth profiles by the alamar Blue ${ }^{\circledR}$ assay. The alamar Blue ${ }^{\circledR}$ was used as the cell viability assay, and many researchers also evaluated to the cell proliferation. Fukuhira et al. evaluated to the proliferation of NIH3T3 cells on honeycomb-patterned film prepared by poly(lactide) and dioleoylphosphatidylethanolamine as adducing. ${ }^{20}$ Moreover, Tsiridis et al. ${ }^{42,43}$ and Disilvio et al. ${ }^{44}$ also evaluated to cell proliferation by alamar Blue assay ${ }^{\circledR}$. The cell number actually increased with incubating time and the cells surely proliferated in the porous structure of the scaffold 


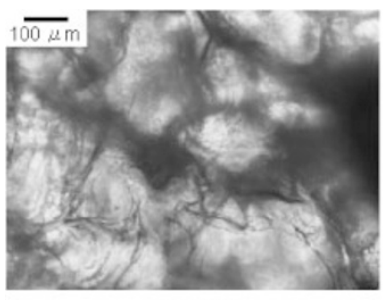

Before

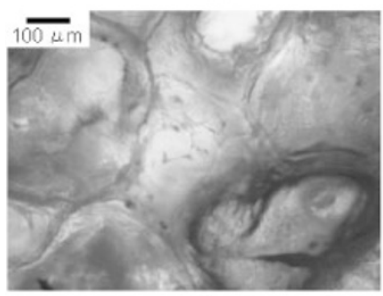

$3 d$

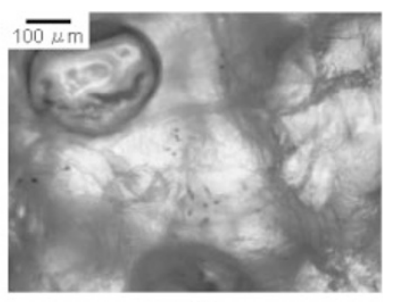

$1 \mathrm{~d}$

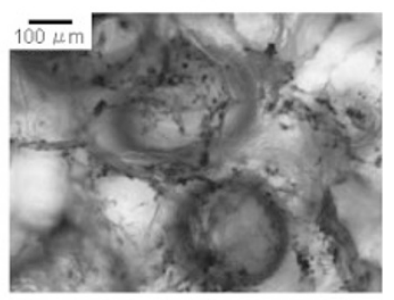

$7 \mathrm{~d}$
Figure 6. Microscopic views of HBCC adhered to CL-LA70/30ss250 surface with incubation periods.

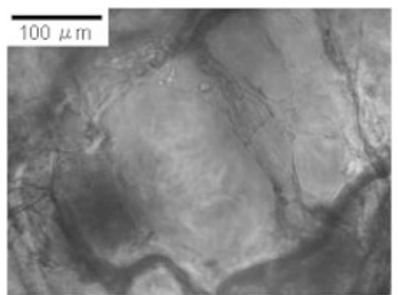

Before

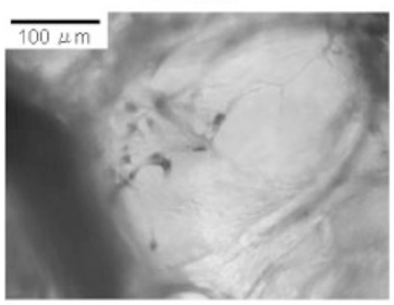

$3 d$

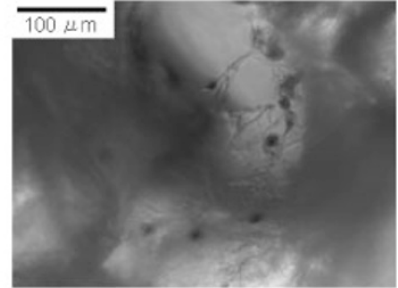

$1 \mathrm{~d}$

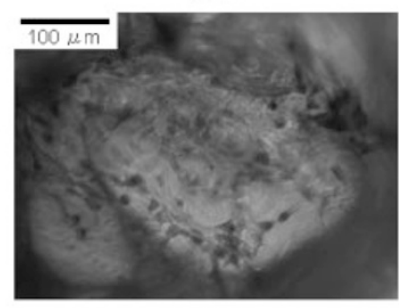

$7 \mathrm{~d}$
Figure 7. Microscopic views of HBCC adhered to CL-LA70/30ss250 inside with incubation periods.

prototype. As reported in our previous study, the starting materials for the prototype show good cell adhesion, spreading and proliferation. These characters are taken over in the scaffold prototype. In terms of biodegradation of the materials, we have confirmed the enzyme degradation using a lipase preliminarily (data not shown). For the practical regeneration of the bladder, we need more precise studies such as tissue compatibility, permeability mechanical strength and so on.

Consequently, we could confirm the feasibility of the new type of scaffold with retractility such a rubber. Moreover, since the starting materials are macromonomer type they are capable of introducing other functional groups by copolymerization. The groups would contribute to proper modification or immobilization of bioactive molecules on the scaffold surfaces. We will report the new studies of more functional scaffold materials in the future.

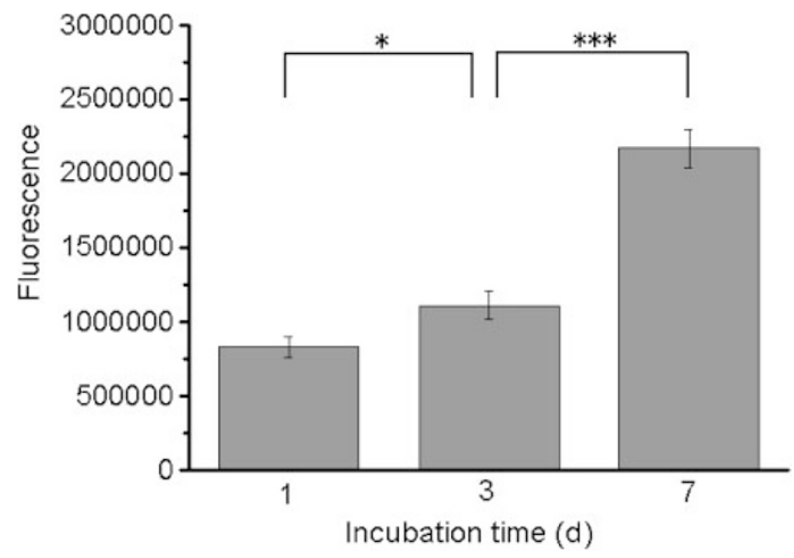

Figure 8. Cell growth of HBCC cultured to CL-LA70/30ss 250 by alamar Blue ${ }^{\circledR}$ assay $(n=3) .{ }^{*} p<0.05$ and ${ }^{* * *} P<0.001$ indicate that between $1 \mathrm{~d}$ and $3 \mathrm{~d}, 3 \mathrm{~d}$ and $7 \mathrm{~d}$ cell culture, these statistically differ on a significant basis.

\section{CONCLUSION}

We succeeded in preparation of flexible scaffold prototype by using branched macromonomer with CL/LA (70/30 mol \%) and salt-leaching method with $\mathrm{NaCl}$ particles with different size. From results of porosity estimation by gravimetry, internal morphology observation by SEM, and water uptake measurement in $\mathrm{PBS}(-)$ at $37^{\circ} \mathrm{C}$, it is proved that these scaffold prototypes could be supplied the good cell growth environment. Moreover, it is suggested that these materials were a good biocompatibility by cell growth assay of HBCC. Consequently, we expected that the prototype prepared in this study would be utilized for scaffold materials in practical tissue engineering application.

Acknowledgment. We are grateful to the Musashino Chemical Laboratory (Tokyo Japan) for kindly providing D,L-lactide and also express our gratitude to Dr. Enokida, Department of Urology of Graduate School of Medical and Dental Science in Kagoshima University for supplying the human bladder cancer cells.

Received: February 4, 2008

Accepted: May 14, 2008

Published: July 9, 2008

\section{REFERENCES}

1. J. J. Marler, J. Upton, R. Langer, and J. P. Vacanti, Adv. Drug Delivery Rev., 33, 165 (1998).

2. S. Y. Lee, J. H. Oh, J. C. Kim, Y. H. Kim, S. H. Kim, and J. W. Choi, Biomaterials, 24, 5049 (2003).

3. N. Isogai, S. Asamura, T. Higashi, Y. Ikada, S. Morita, J. Hillyer, R. Jacquet, and W. J. Landis, Tissue Engineering, 10, 673 (2004).

4. Y. Sumita, M. J. Honda, T. Ohara, S. Tsuchiya, H. Sagara, H. Kagami, and M. Ueda, Biomaterials, 27, 3238 (2006).

5. F. Couet, N. Rajan, and D. Mantovani, Macromol. Biosci., 7, 701 (2007).

6. K. W. Ng and D. W. Hutmacher, Biomaterials, 27, 4591 (2006). 
7. L. Lu, S. J. Peter, M. D. Lyman, H.-L. Lai, S. M. Leite, J. A. Tamada, S. Uyama, J. P. Vacanti, R. Langer, and A. G. Mikos, Biomaterials, 21, 1837 (2000).

8. L. Guan and J. E. Davies, J. Biomed. Mater. Res., 71A, 480 (2004).

9. L. Wu and J. Ding, Biomaterials, 25, 5821 (2004).

10. L. Wu, J. Zhang, D. Jing, and J. Ding, J. Biomed. Mater. Res., 76A, 264 (2006).

11. J. E. Babensee, J. M. Anderson, L. V. McIntire, and A. G. Mikos, Adv. Drug Delivery Rev., 33, 111 (1998).

12. V. Karageorgiou and D. Kaplan, Biomaterials, 26, 5474 (2005).

13. H. Miyasako, K. Yamamoto, A. Nakao, and T. Aoyagi, Macromol. Biosci., 7, 76 (2007).

14. C.-T. Lee, C.-P. Huang, and Y.-D. Lee, Biomacromolecules, 7, 2200 (2006).

15. R. K. Srivastava and A.-C. Albertsson, Biomacromolecules, 7, 2531 (2006).

16. M. Takemoto, T. Shirahama, T. Miyauchi, T. Matsusako, N. Kaneda, H. Muramatsu, M. Ozawa, Y. Ohi, and T. Muramatsu, Int. J. Cancer (Pred. Oncol.), 74, 7 (1997).

17. T. Kayajima, T. Shirahama, I. Yanase, and Y. Ohi, Jap. J. Urol. Surg., 2, 577 (1989).

18. D. W. Hutmacher, T. Schantz, I. Zein, K. W. Ng, S. H. Teoh, and K. C. Tan, J. Biomed. Mater. Res., 55A, 203 (2001).

19. J. Watanabe and K. Ishihara, Biomacromolecules, 6, 1797 (2005).

20. Y. Fukuhira, E. Kitazono, T. Hayashi, H. Kaneko, M. Tanaka, M. Shimomura, and Y. Sumi, Biomaterials, 27, 1797 (2006).

21. A. S. Karikari, W. F. Edward, J. B. Mecham, and T. E. Long, Biomacromolecules, 6, 2866 (2005).

22. J. Y. Shen, X. Y. Pan, C. H. Lim, M. B. Chan-Park, X. Zhu, and R. W. Beuerman, Biomacromolecules, 8, 376 (2007).

23. K. Nagahama, Y. Nishimura, Y. Ohya, and T. Ouchi, Polymer, 48, 2649 (2007).

24. K. Uto, K. Yamamoto, S. Hirase, and T. Aoyagi, J. Controlled Release, 110, 408 (2006).

25. F. A. Maspero, K. Ruffieux, B. Müller, and E. Wintermantel, J. Biomed. Mater. Res., 62A, 89 (2002).
26. Y. Hu, D. W. Grainger, S. R. Winn, and J. O. Hollinger, J. Biomed. Mater. Res., 59A, 563 (2002).

27. Y.-Y. Hsu, J. D. Gresser, D. J. Trantolo, C. M. Lyons, P. R. J. Gangadharam, and D. L. Wise, J. Biomed. Mater. Res., 35A, 107 (1997).

28. R. Zhang and P. X. Ma, J. Biomed. Mater. Res., 44A, 446 (1999).

29. R. Nazarov, H.-J. Jin, and D. L. Kaplan, Biomacromolecules, 5, 718 (2004).

30. E. A. Botchwey, S. R. Pollack, E. M. Levine, and C. T. Laurencin, J. Biomed. Mater. Res., 55A, 242 (2001).

31. G. Chen, T. Ushida, and T. Tateishi, J. Biomed. Mater. Res., 57A, 8 (2001).

32. S. H. Oh, S. G. Kang, E. S. Kim, S. H. Cho, and J. H. Lee, Biomaterials, 24, 4011 (2003).

33. S. Nishiguchi, H. Kato, M. Neo, M. Oka, H.-M. Kim, T. Kokubo, and T. Nakamura, J. Biomed. Mater. Res., 54, 198 (2001).

34. S.-N. Park, J.-C. Park, H. O. Kim, M. J. Song, and H. Suh, Biomaterials, 23, 1205 (2002).

35. J. Mao, L. Zhao, K. de Yao, Q. Shang, G. Yang, and Y. Cao, J. Biomed. Mater. Res., 64A, 301 (2003).

36. T. K. Kim, J. J. Yoon, D. S. Lee, and T. G. Park, Biomaterials, 27, 152 (2006)

37. J. M. Oliveira, M. T. Rodrigues, S. S. Silva, P. B. Malafaya, M. E. Gomes, C. A. Viegas, I. R. Dias, J. T. Azevedo, J. F. Mano, and R. L. Reis, Biomaterials, 27, 6123 (2006).

38. D.-J. Yang, L.-F. Zhang, L. Xu, C.-D. Xiong, J. Ding, and Y.-Z Wang, J. Biomed. Mater. Res., 82A, 680 (2007).

39. R. A. Stile and K. E. Healy, Biomacromolecules, 2, 185 (2001).

40. R. A. Stile and K. E. Healy, Biomacromolecules, 3, 591 (2002).

41. S. Kim and K. E. Healy, Biomacromolecules, 4, 1214 (2003).

42. E. Tsiridis, Z. Ali, A. Bhalla, M. Heliotis, N. Gurav, S. Deb, and L. DiSilvio, J. Orthopaedic Research Society, 7, 1425 (2007).

43. E. Tsiridis, A. Bhalla, Z. Ali, N. Gurav, M. Heliotis, S. Deb, and L. Disilvio, Injury, Int. J. Care Injured, 37S, S25 (2006).

44. L. DiSilvio, J. Jameson, Z. Gamie, P. V. Giannoudis, and E. Tsiridis, Injury, Int. J. Care Injured, 37S, S33 (2006). 